\title{
Varietal Response of Chickpea (Cicer arietinum L.) Towards the Allelopathy of Different Weeds
}

(Respons Varieti Kacang Kuda (Cicer arietinum L.) kepada Alelopati Rumpai yang Berbeza)

\author{
RAHAMDAD KHAN* \& IJAZ AHMAD KHAN
}

\begin{abstract}
In a laboratory trial three chickpea varieties viz, Karak-I, Karak-III and Shenghar were tested against the phytotoxicity of five weed species: Parthenium hysterophorus L., Phragmites australis (Cav.) Trin., Datura alba L., Cyperus rotundus $L$. and Convolvulus arvensis L. in January 2013. The weed extracts were prepared at the rate of $120 \mathrm{~g} / \mathrm{L}(\mathrm{w} / \mathrm{v})$ after shade dry. The results indicated highly significant inhibitory effect of all the tested weed species on the chickpea varieties. The results also showed that the chickpea variety Karak-III was more susceptible to the phytotoxcity of the tested weed extracts. Among the extract, C. arvensis proved much toxic in term of inhibition of germination by giving only $43.33 \%$ germination in comparison with control where $97.50 \%$ germination was recorded. On the other hand, the effect of $\mathrm{P}$. australis extract was found a little stimulator by speeding the seed germination in all varieties and giving a low (2.21) mean germination time (MGT) value. From the current results it can be concluded that the infestation of $\mathrm{C}$. arvensis can pollute the soil by accumulating toxic chemicals that leads to the germination failure and growth suppression in chickpea. Therefore, the prevention and removal of $\mathrm{C}$. arvensis in the chickpea growing areas could be recommended. In addition, $\mathrm{P}$. australis must be tested against chickpea weeds (chickpea varieties withstand against its phytotoxcity), so that it can be popularized as bioherbicide in chickpea if it gave promising results in controlling chickpea weeds.
\end{abstract}

Keywords: Allelopathy; chickpea; germination; Parthenium; weeds

ABSTRAK

Tiga varieti kacang kuda iaitu, Karak-I, Karak-III dan Shenghar telah diuji dalam makmal rintis terhadap fitoketoksikan lima spesies rumpai: Parthenium hysterophorus L., Phragmites australis (Cav.) Trin., Datura alba L., Cyperus rotundus L. dan Convolvulus arvensis L. pada bulan Januari 2013. Ekstrak rumpai telah disediakan pada kadar $120 \mathrm{~g} / \mathrm{L}(\mathrm{w} / \mathrm{v})$ selepas diteduh kering. Keputusan menunjukkan kesan rencat yang ketara daripada semua spesies rumpai yang diuji dengan pelbagai jenis kacang kuda. Keputusan juga menunjukkan bahawa kacang kuda jenis Karak-III adalah lebih terdedah kepada fitoketoksikan ekstrak rumpai yang diuji. Antara ekstrak, C. arvensis terbukti mempunyai banyak toksik daripada segi perencatan percambahan dengan memberi $43.33 \%$ percambahan berbanding kawalan dengan $97.50 \%$ percambahan direkod. Sebaliknya, kesan ekstrak P. australis didapati memberi sedikit perangsang dengan mempercepatkan percambahan biji benih dalam semua varieti dan memberi nilai masa (MGT) (2.21) percambahan min yang rendah. Daripada keputusan ini, dapat disimpulkan bahawa serangan daripada C. arvensis boleh mencemarkan tanah dengan toksik kimia terkumpul yang membawa kepada kegagalan percambahan dan penindasan pertumbuhan kacang kuda. Oleh itu, pencegahan dan penghapusan C. arvensis di kawasan penanaman kacang kuda boleh disyorkan. Di samping itu, P. australis mesti diuji terhadap rumpai kacang kuda (varieti kacang kuda menentang fitoketoksikannya), supaya ia boleh dipopularkan sebagai racun herba biologi kacang kuda jika ia memberikan keputusan yang memberangsangkan dalam kawalan rumpai kacang kuda.

Kata kunci: Alelopati; kacang kuda; percambahan; Parthenium; rumpai

\section{INTRODUCTION}

Chickpea (Cicer arietinum L.) has a great importance as pulse as well as a vegetable crop in Pakistan and also in Khyber Pakhtunkhwa (KPK). The yield of chickpea in the developed countries is much more as compared to Pakistan and the factors responsible for low yield in Pakistan are poor soil, inadequate moisture, harsh climatic conditions, weeds and inadequate or even no fertilizer supply (Aslam et al. 1996). Besides competing for moisture, nutrients and light, weeds can also affect crop growth by releasing allelochemicals into the growing environment (Kadioglue et al. 2005). All plant parts of the weed including leaf, stem, root and fruit have allelopathic potential and their efficacy on germination and seedling growth of crops varies from weed to weed (Tinnin \& Muller 2006). The allelopathic effects of various parts of the same weed also differ for their effects on germination and initial growth of plants (Aziz et al. 2008). However, various parts of weeds show different behavior in exerting their allelopathic effects on crops (Veenapani 2004). Weeds also exert allelopathic 
effects on crop seed germination and growth by releasing water-soluble compounds into the soil (Batish et al. 2007). Many studies have confirmed that chemicals with allelopathic potential are present in leaves, stems, flowers, roots, seeds and buds. Several researchers have reported the suppression of weed by the crops under field conditions. The superior weed suppressing genotypes have been reported in cucumber, oat, rice, sunflower, soybean, sorghum, pearl millet and Brassica campestris (Ata \& Jamil 2001). These allelochemicals offer great potential to be used as pesticides because they are free from problems associated with the present pesticides.

The use of allelopathic water extracts is inexpensive and environment gracious, reduction in weed biomass is less than herbicides and manual weeding. Allelopathy may be used as a tool in weed management by applying the residues of allelopathic weeds or crop plants as mulches water extracts in the field (Matloob et al. 2010).

In most arid regions of the country, chickpea is the main crop grown due to climatic suitability and due to their direct consumption for nutritional purpose. Therefore, agriculturists of the region are mainly focusing on all the possible yield reducing factors in chickpea. Among the various yield reducing factors in crops, one most important factor is the failure of seed germination of crop in soil. This failure is mainly assigned with the accumulation of weeds extract/debris (allelochemicals) present in soil that leaches in soil through ploughing or rain water (Khan et al. 2012).

In order to provide more precise information for chickpea growers regarding the negative impact of different weeds present in chickpea field in term of releasing harmful chemicals in the soil, this study aimed to determine the possible ill effect of different weeds on different chickpea varieties under laboratory conditions.

\section{MATERIALS AND METHODS}

\section{EXPERIMENTAL DETAILS}

The experiment was carried out at Weed Science Research Laboratory, The University of Agriculture Peshawar, Pakistan in January 2013. The experimental design used was a completely randomized design with factorial arrangements repeated four times. The Factor A comprised of three chickpea varieties (Karak-I, Karak-III and Shenghar) while the Factor B consisted the water extracts of five weed species i.e.Parthenium hysterophorus L., Phragmites australis (Cav.) Trin., Datura alba L., Cyperus rotundus L. and Convolvulus arvensis L. Similarly, a distilled water treatment was kept as control for comparison.

\section{SAMPLE COLLECTION AND EXTRACT PREPARATION}

The above mentioned weeds were collected randomly from the research fields of New Developmental Research Farm of the University of Agriculture, Peshawar, Pakistan. Whole plants were collected by cutting the plants at the base (above the ground) with a sickle. Then the plants were washed with tap water to wash down the dust and other particles and then dried in shade. After drying, the whole plants (roots, stems, leaves and fruits) were first chopped and then ground with the help of grinder. The dried powder of the weed species were weighed and mixed in tap water at the rate of $120 \mathrm{~g} \mathrm{~L}^{-1}$ to make concentrated extract at room temperature for $24 \mathrm{~h}$. The final water extracts of the different weeds were obtained by filtering process through 10 and 60-mesh sieves. All the prepared weed extracts were individually bottled and tagged for further process in the experimentation.

\section{TREATMENT APPLICATION}

First of all, ten seeds of each chickpea variety were put separately in petri dishes (each having $9 \mathrm{~cm}$ in diameter) containing three layers of Whatman No.1 filter paper. The petri dishes were replicated four times. Three $\mathrm{mL}$ plant extract as per treatment was added to each petri dish and distilled water was used as a control treatment for comparison. The petri dishes were observed daily and an equal amount of extract was added to each petri dish as needed to prevent seeds or seedlings from drying out. The whole experimental setup was continued for 10 days. During the course of study, the data were recorded for seed germination $(\%)$, seedling length $(\mathrm{cm})$, mean germination time (MGT), germination index (GI) and seedling vigor index (SVI). The recorded data were individually subjected to the ANNOVA procedure using MSTATC computer software and means were separated by using Fisher's LSD test (Steel et al. 1997).

\section{RESULTS AND DISCUSSION}

\section{GERMINATION}

Statistical analysis of the data showed significant impact of the aqueous extract of different weed species on germination $(\%)$ of chickpea varieties (Table 1). The weed extract means separation showed that maximum germination $(97.50 \%$ ) was noted for control treatment (no extract), which was statistically at par with the effect on $P$. australis (96.66\%) and minimum germination (43.33\%) was observed for $C$.arvensis. On the other hand, the data for the variety mean showed that the percent germination of the all tested chickpea varieties was significantly affected, especially for the chickpea variety Karak-III that gave a minimum germination (75.41\%) against the tested weed extracts. While chickpea variety Karak-I gave the highest germination $(86.66 \%)$ toward the different weed extracts (Table 1). Similarly, in case of interaction of weed extracts and tested chickpea varieties, the highest germination (100\%) was recorded for the control treatment (no extract) in both the tested chickpea varieties Karak-I and Shenghar while minimum seed germination (27.5\%) was noted for $C$.arvensis x variety Karak-III. The presence of allelochemicals has been explored many times and many 
TABLE 1 . Germination (\%) of chickpea varieties as affected by different weeds extracts

\begin{tabular}{lcccc}
\hline \multirow{2}{*}{ Weed extract } & \multicolumn{3}{c}{ Varieties } & \multirow{2}{*}{ Means } \\
\cline { 2 - 4 } & Karak-I & Karak-III & Sheenghar & \\
\hline Parthenium hysterophorus & $92.50 \mathrm{abc}$ & $87.50 \mathrm{abc}$ & $87.50 \mathrm{abc}$ & $89.16 \mathrm{ab}$ \\
Phragmites australis & $97.50 \mathrm{a}$ & $95.0 \mathrm{ab}$ & $97.50 \mathrm{a}$ & $96.66 \mathrm{a}$ \\
Datura alba & $80.0 \mathrm{bcd}$ & $80.0 \mathrm{bcd}$ & $80.0 \mathrm{bcd}$ & $80.00 \mathrm{~b}$ \\
Cyperus rotundus & $92.50 \mathrm{abc}$ & $70.0 \mathrm{de}$ & $77.50 \mathrm{~cd}$ & $80.00 \mathrm{~b}$ \\
Convolvulus arvensis & $57.50 \mathrm{ef}$ & $27.5 \mathrm{~g}$ & $45.0 \mathrm{f}$ & $43.33 \mathrm{c}$ \\
Control (No extract) & $100.0 \mathrm{a}$ & $92.50 \mathrm{abc}$ & $100.0 \mathrm{a}$ & $97.50 \mathrm{a}$ \\
Means & $86.66 \mathrm{a}$ & $75.41 \mathrm{~b}$ & $81.25 \mathrm{ab}$ & \\
\hline
\end{tabular}

LSD (0.05) for weed extract: 9.435

LSD (0.05) for Varieties: 6.745

LSD (0.05) for weed extract $x$ varieties: 16.342

scientists are of the view that allelopathins are present in various parts of plants and can greatly affect the receiver plants in many ways. However, allelochemicals are synthesized in plants as secondary metabolites and located in certain specialized organs of donor plants (Kobayashi 2004). In similar investigation Khan et al. (2011) also reported $60 \%$ germination inhibition in chickpea against aqueous extract of Silybum marianum tested at different concentrations.

\section{SEEDLING LENGTH}

Analysis of variance of the data showed that different weed extracts had significant effect on the seedling length of the tested chickpea varieties (Table 2) (Figures 1-5). Extract means showed that maximum seedling length $(9.95 \mathrm{~cm})$ was recorded for P. australis (Figure 2) while the lowest $(1.02 \mathrm{~cm})$ was observed for $C$.arvensis (Figure 5) which was statistically similar with Cyperus rotundus (Figure 4). Like weed extract means the results of variety means also addressed the significant results in term of seedling length. Maximum seedling length $(4.57 \mathrm{~cm})$ was observed for variety Shenghar that was statistical comparable with chickpea variety Karak-I while variety Karak-III produced the shorter seedling $(3.83 \mathrm{~cm})$ among the varieties against different weed extracts. Interaction between weed extract and chickpea varieties was also highly significant regarding seedling length parameter. The most lengthy seedling $(11.30 \mathrm{~cm})$ was noted under the combination of $P$. australis $\mathrm{x}$ variety Sheenghar (Figure 2) and the shorter seedling $(0.20 \mathrm{~cm})$ was found for $C$. arvensis x variety Karak-III (Figure 5). These results are the clear evidence of the presence of phytotoxic chemicals in the studied weed species. In a similar study, Cheema and Khaliq (2000) reported that allelochemicals have the capability to inhibit or retard the root and shoot of the crops as well as the weeds and could be successfully used in weed management techniques. However, the presence of allelochemicals in

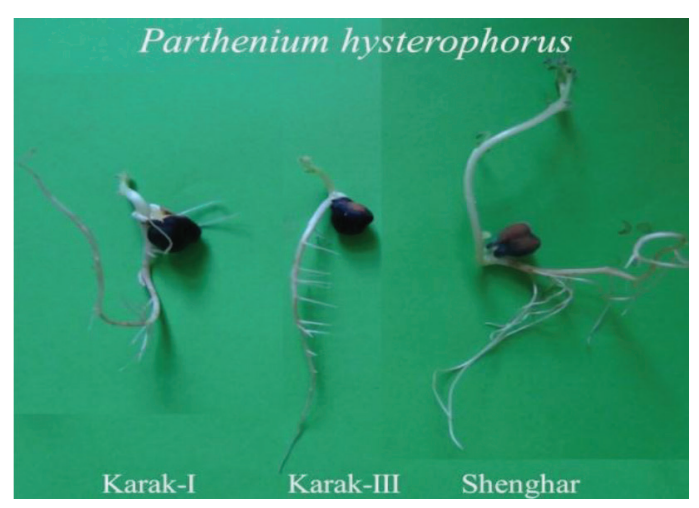

FIGURE 1. Effect of Parthenium hysterophorus extract on chickpea varieties

TABLE 2. Seedling length $(\mathrm{cm})$ of chickpea varieties as affected by different weeds extracts

\begin{tabular}{lcccc}
\hline \multirow{2}{*}{ Weed extract } & \multicolumn{3}{c}{ Varieties } & \multirow{2}{*}{ Means } \\
\cline { 2 - 4 } & Karak-I & Karak-III & Shenghar & \\
\hline Parthenium hysterophorus & $2.80 \mathrm{f}$ & $2.40 \mathrm{fg}$ & $1.30 \mathrm{j}$ & $2.16 \mathrm{c}$ \\
Phragmites australis & $9.05 \mathrm{~d}$ & $9.50 \mathrm{c}$ & $11.30 \mathrm{a}$ & $9.95 \mathrm{a}$ \\
Datura alba & $4.42 \mathrm{e}$ & $0.80 \mathrm{k}$ & $1.80 \mathrm{hi}$ & $2.34 \mathrm{c}$ \\
Cyperus rotundus & $1.40 \mathrm{ij}$ & $1.30 \mathrm{j}$ & $0.50 \mathrm{kl}$ & $1.06 \mathrm{~d}$ \\
Convolvulus arvensis & $0.80 \mathrm{k}$ & $0.20 \mathrm{l}$ & $2.07 \mathrm{gh}$ & $1.02 \mathrm{~d}$ \\
Control (No extract) & $8.80 \mathrm{~d}$ & $8.80 \mathrm{~d}$ & $10.50 \mathrm{~b}$ & $9.36 \mathrm{~b}$ \\
Means & $4.54 \mathrm{a}$ & $3.83 \mathrm{~b}$ & $4.57 \mathrm{a}$ & \\
\hline
\end{tabular}

LSD (0.05) for weed extract: 0.245

LSD $(0.05)$ for Varieties: 0.139

LSD $(0.05)$ for weed extract $x$ varieties: 0.425 


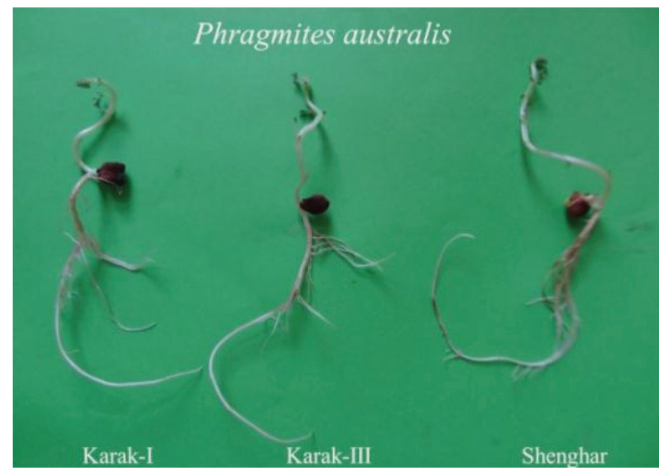

FIGURE 2. Effect of Phragmites australis extract on chickpea varieties

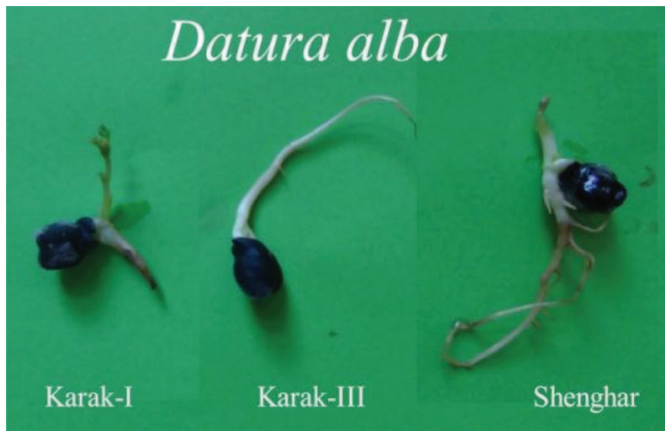

FIGURE 3. Effect of Datura alba extract on chickpea varieties

plants depends on many factors. In other studies, Saeed et al. (2011) also found the lowest shoot length of horse purslane treated with Helianthus annuus water extract. Furthermore, Sorghum water extract significantly reduced shoot length of Trianthima portulacastrum (Randhawa et al. 2002).

\section{MEAN GERMINATION TIME}

The lower the MGT value, the earlier will be the germination and vice versa i.e. the MGT value expresses the rapidity of the germination. The results reported in Table 3 shows that the examined weed extracts were highly toxic against all the three tested chickpea varieties because it gave significant results regarding germination speed. The extracts mean data showed that the lowest MGT (2.21) was noted for $P$. australis while the highest MGT (4.08) was recorded for the extract of $C$. arvensis. The chickpea variety Shenghar was capable to germinate quickly because it gave the minimum MGT value (2.83) and the variety Karak-III showed late germination by giving the maximum MGT value (3.78). The interaction exhibits that maximum MGT value (5.50) attained by the combination $C$. rotundus $\mathrm{x}$ variety KarakIII, while the minimum value (1.71) was obtained for the combination $P$. australis x variety Shenghar. Babar et al. (2009) also found that the germination of chickpea seeds was slowed down when treated with the root extract of Asphodelus tenuifolius Cav. Similarly, Khan et al. (2011)

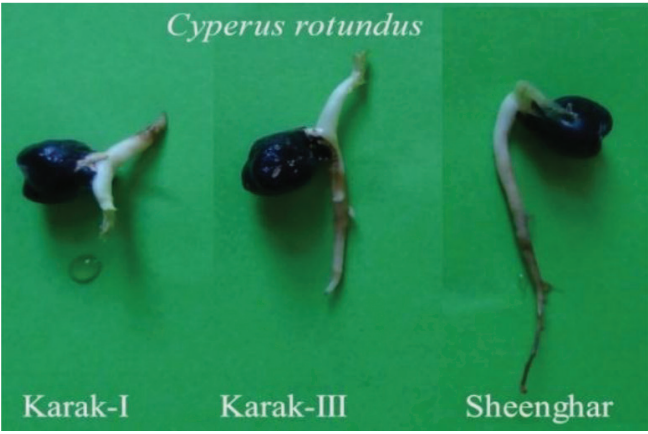

FIGURE 4. Effect of Cyperus rotundus extract on chickpea varieties

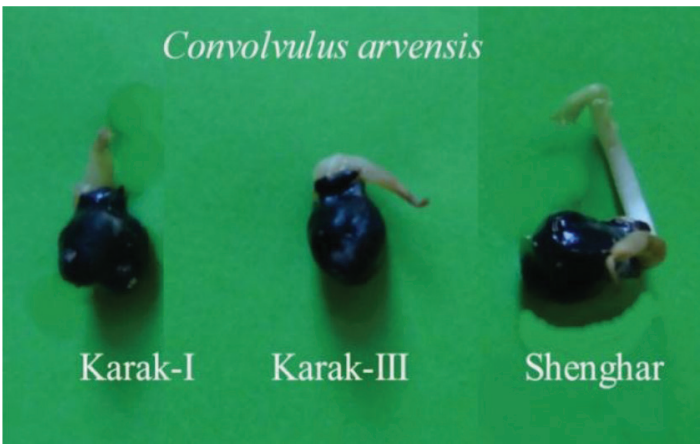

FIGURE 5. Effect of Convolvulus arvensis extract on chickpea varieties

found high value of mean germination time in chickpea tested against Silybum marianum.

\section{GERMINATION INDEX}

The GI is directly correlated with seed germination percentage. Thus, the greater GI value the greater germination percentage will be. The present findings showed that different weed extracts significantly affected the germination index as compared with control treatments. The data on GI (Table 4) showed that the highest extract mean (5.46) was observed in $P$. australis followed by $P$. hysterophorus (3.69) while the lowest GI was recorded for $C$. arvensis (1.26). Like the extract mean the varieties means also varied and posed a significant effect on the GI value. The maximum GI value (3.69) was found for Shenghar variety while the minimum GI value (2.42) was observed in variety Karak-III. As for interaction mean, the highest GI value (6.68) was noted under the combination of $P$. australis extract $x$ variety Shenghar, while the minimum (0.57) was obtained for the combination of C.arvensis x variety Karak-III. In another study, Tanveer et al. (2008) found smaller GI value in rice treated with the aqueous extract of Xanthium strumarium.

\section{SEED VIGOUR INDEX}

The analysis of variance showed that weed extracts, the chickpea varieties and their interactions had high 
TABLE 3. Mean germination time (MGT) of chickpea varieties as affected by different weeds extracts

\begin{tabular}{|c|c|c|c|c|}
\hline \multirow{2}{*}{ Weed extract } & \multicolumn{3}{|c|}{ Varieties } & \multirow{2}{*}{ Means } \\
\hline & Karak-I & Karak-III & Shenghar & \\
\hline Parthenium hysterophorus & 3.13 defg & $3.22 \mathrm{defg}$ & 2.33 hij & $2.89 \mathrm{~b}$ \\
\hline Phragmites australis & $2.04 \mathrm{ij}$ & 2.90 efgh & $1.71 \mathrm{j}$ & $2.21 \mathrm{c}$ \\
\hline Datura alba & 2.64 fghi & 3.20 defg & $2.50 \mathrm{ghi}$ & $2.78 \mathrm{~b}$ \\
\hline Cyperus rotundus & $3.35 \mathrm{def}$ & $5.20 \mathrm{a}$ & $3.37 \mathrm{def}$ & $3.97 \mathrm{a}$ \\
\hline Convolvulus arvensis & 3.65 cde & $4.45 \mathrm{~b}$ & $4.15 \mathrm{bc}$ & $4.08 \mathrm{a}$ \\
\hline Control (No extract) & 2.72 fghi & $3.69 \mathrm{~cd}$ & 2.92 defgh & $3.11 \mathrm{~b}$ \\
\hline Means & $2.92 \mathrm{~b}$ & $3.78 \mathrm{a}$ & $2.83 \mathrm{~b}$ & \\
\hline
\end{tabular}

LSD $(0.05)$ for weed extract: 0.469

LSD $(0.05)$ for Varieties: 0.405

LSD (0.05) for weed extract $x$ varieties: 0.7014

TABLE 4. Germination Index (GI) of chickpea varieties as affected by different weeds extracts

\begin{tabular}{lcccc}
\hline \multirow{2}{*}{ Weed extract } & \multicolumn{3}{c}{ Varieties } & \multirow{2}{*}{ Means } \\
\cline { 2 - 4 } & Karak-I & Karak-III & Shenghar & $3.69 \mathrm{~b}$ \\
\hline Parthenium hysterophorus & $3.64 \mathrm{bcde}$ & $2.97 \mathrm{cdef}$ & $4.48 \mathrm{~b}$ & $5.46 \mathrm{a}$ \\
Phragmites australis & $5.75 \mathrm{a}$ & $3.96 \mathrm{bc}$ & $6.68 \mathrm{a}$ & $3.22 \mathrm{~b}$ \\
Datura alba & $3.16 \mathrm{cde}$ & $2.81 \mathrm{defg}$ & $3.69 \mathrm{bcde}$ & $2.13 \mathrm{c}$ \\
Cyperus rotundus & $2.80 \mathrm{efg}$ & $1.61 \mathrm{hij}$ & $1.96 \mathrm{fghi}$ & $1.26 \mathrm{~d}$ \\
Convolvulus arvensis & $1.80 \mathrm{ghi}$ & $0.57 \mathrm{j}$ & $1.41 \mathrm{ij}$ & $3.48 \mathrm{~b}$ \\
Control (No extract) & $3.87 \mathrm{bcd}$ & $2.63 \mathrm{efgh}$ & $3.94 \mathrm{bc}$ & $3.69 \mathrm{a}$ \\
Means & $3.50 \mathrm{a}$ & $2.42 \mathrm{~b}$ & & \\
\hline
\end{tabular}

LSD (0.05) for weed extract: 0.600

LSD (0.05) for Varieties: 0.555

LSD (0.05) for weed extract $x$ varieties: 1.040

TABLE 5. Seed Vigor Index (SVI) of chickpea varieties as affected by different weeds extracts

\begin{tabular}{lcccc}
\hline \multirow{2}{*}{ Weed extract } & \multicolumn{3}{c}{ Varieties } & \multirow{2}{*}{ Means } \\
\cline { 2 - 4 } & Karak-I & Karak-III & Shenghar & $194.17 \mathrm{c}$ \\
\hline Parthenium hysterophorus & $258.8 \mathrm{e}$ & $210.0 \mathrm{ef}$ & $113.8 \mathrm{ghi}$ & $962.0 \mathrm{a}$ \\
Phragmites australis & $882.5 \mathrm{bc}$ & $902.0 \mathrm{~b}$ & $1101.8 \mathrm{a}$ & $189.2 \mathrm{c}$ \\
Datura alba & $359.8 \mathrm{~d}$ & $64.0 \mathrm{hijk}$ & $144.0 \mathrm{fg}$ & $86.4 \mathrm{~d}$ \\
Cyperus rotundus & $129.5 \mathrm{gh}$ & $91.0 \mathrm{ghij}$ & $38.8 \mathrm{jk}$ & $48.5 \mathrm{~d}$ \\
Convolvulus arvensis & $46.0 \mathrm{ijk}$ & $5.5 \mathrm{k}$ & $94.0 \mathrm{ghij}$ & $914.67 \mathrm{~b}$ \\
Control (No extract) & $880.0 \mathrm{bc}$ & $814.0 \mathrm{c}$ & $1050.0 \mathrm{a}$ & $423.7 \mathrm{a}$ \\
Means & $426.0 \mathrm{a}$ & $347.7 \mathrm{~b}$ & &
\end{tabular}

LSD $(0.05)$ for weed extract: 40.411

LSD (0.05) for Varieties: 32.593

LSD $(0.05)$ for weed extract $x$ varieties: 69.994

significant SVI values. The mean data of weed extracts presented in Table 5 shows that the SVI values of the tested chickpea varieties recorded were highly significant. Means of the weed extracts showed that maximum SVI value (962) was recorded for P. australis, while the lowest SVI (48.5) was found in C.arvensis. Likewise the variety means were also significantly affected SVI values in the present study. The highest SVI mean value (426) for varieties was recorded for Karak-I while the lowest (347.7) was recorded for Karak-III. The interaction mean data presented that the maximum SVI value (1050.0) attained by the treatment control (no extract) $\mathrm{x}$ variety Shenghar, while the minimum value (5.5) was observed for the combination $C$. arvensis x variety Karak-III. Mubeen et al. (2011) also observed that Trianthima portulacastrum leaf extract greatly reduced the SVI of rice. Our current findings are greatly analogous to the results of Khan et al. (2012) who found inhibition in root and shoot lengths of different wheat seed when exposed to extracts from various plant parts of Parthenium hysterophorus L. 


\section{CONCLUSION AND RECOMMENDATIONS}

The presence of allelopathic weeds in the chickpea fields may pose a serious threat to the production as these weeds will release allelopathins to the soil environment and thus could result in failure of seed germination. The toxic chemicals from the tested weed species may be released by rain or irrigation and dissolved in water under field conditions. Therefore, the presence of P. hysterophorus, $P$. australis, D. alba, C. rotundus and especially C.arvensis in chickpea fields should be controlled at early stage to avoid phytotoxic allelopathic effects of these weeds on crop seed. Moreover, we suggest that the chickpea grower to avoid cultivating chickpea variety Karak-III as it was proved to be much susceptible towards the phytotoxicity of the studied weed species. Further studies are proposed under field conditions that may investigate the inhibitive effects of these weeds against the associated chickpea weed species because these weeds provide opportunity to be used for weed management as a bioherbicide in future. $P$. australis showed non-toxic effect on chickpea seeds and therefore, there is a possibility to explore this weed against chickpea weeds.

\section{REFERENCES}

Ata, Z. \& Jamil, M. 2001. Allelopathic suppression of weeds: A new field in need of attention. Daily Dawn, December $31,2001$.

Aslam, M., Khokhar, J.D., Mahmood Sultan, I.A.T. \& Ahmad, S. 1996. PARC Annual Report. Pak. Agri. Res. Council, Islamabad. pp. 95-96.

Aziz, A., Tanveer,A.,Ali, M., Yasin, M., Babar, B.H. \& Nadeem, M.A. 2008. Allelopathic effect of cleavers (Galium aparine) on germination and early growth of wheat (Triticum aestivum). Allelopathy Journal 22: 25-34.

Babar, B.H., Tanveer, A., Tahir, M., Aziz, A., Ahmad, A.U.H., Nadeem, M.A. \& Javaid, M.M. 2009. Allelopathic potential of wild onion (Asphodelus tenuifolius) on the germination and seedling growth of chickpea (Cicer arietinum). Weed Biology and Management 9: 146-151.

Batish, D.R., Lavanya, K., Singh, H.P. \& Kohli, R.K. 2007. Root mediated allelopathic interference of Nettle-leaved Goosefoot (Chenopodium murale) on wheat (Triticum aestivum). Crop Sciences 193: 37-44.

Cheema, Z.A. \& Khaliq, A. 2000. Use of sorghum allelopathic properties to control weeds in irrigated wheat in a semi-arid region of Punjab. Agriculture Ecosystem and Environment 79: 105-112.

Kadioglue, I., Yanar, Y. \& Asav, U. 2005. Allelopathic effects of weed leachates against seed germination of some plants. Journal of Environmental Biology 26: 169-173.
Khan, N., Hashmatullah, Naveed, K., Hussain, Z. \& Khan, S.A. 2012. Assessment of allelopathic effects of parthenium (Parthenium hysterophorus L.) plant parts on seed germination and seedling growth of wheat (Triticum aestivum L.) cultivars. Pakistan Journal of Weed Science Research 18(1): 39-50.

Khan, R., Khan, M.A., Waheedullah, Waqas, M., Khan, A.M., Hussain, Z., Khan, A. \& Raza, M.A. 2011. Allelopathic potential of Silybum marianum L. against the seed germination of edible legumes. Pakistan Journal of Weed Science Research 17(3): 293-302.

Kobayashi, K. 2004. Factors affecting phytotoxic activity of allelochemicals in soil. Weed Biology and Management 4: 1-7.

Matloob, A., Khaliq, A., Farooq, M. \& Cheema, Z.A. 2010. Quantification of allelopathic potential of different crop residues for the purple nutsedge suppression. Pakistan Journal of Weed Science Research 16(1): 1-12.

Mubeen, K., Nadeem, M.A., Tanveer, A. \& Zahir, Z.A. 2011. Allelopathic effect of aqueous extracts of weeds on the germination and seedling growth of rice (Oryza sativa L.). Pakistan Journal of Life \& Social Sciences 9(1): 87-92.

Randhawa, M.A., Cheema, Z.A. \& Ali, M.A. 2002. Allelopathic effect of sorghum water extract on the germination and seedling growth of Trianthema portulacastrum. International Journal of Agriculture and Biology 4(3): 383-384.

Saeed, M., Ashfaq, M. \& Gul, B. 2011. Effect of different allelochemicals on germination and growth of horse purslane. Pakistan Journal of Botany 43(4): 2113-2114.

Steel, R.G.D., Torrie, J.H. \& Dickey, D. 1997. Principles and Procedure of Statistics: A Biometrical Approach.3rd ed. New York: McGraw Hill Book Co. Inc. pp. 352-358.

Tanveer, A., Tahir, M., Nadeem, M.A., Younis, M., Aziz, A. \& Yaseen, M. 2008. Allelopathic effects of Xanthium strumarium L. on seed germination and seedling growth of crops. Allelopathy Journal 21: 317-328.

Tinnin, R.O. \& Muller, C.H. 2006. The allelopathic influence of Avena fatua. The allelopathic mechanism. Bulletin Torrey Botanical Club 99: 287-292.

Veenapani, D. 2004. Inhibition in seed germination of Oryza sativa (paddy) by two weed species. Flora and Fauna 10: 11-12.

Department of Weed Science

The University of Agriculture, Peshawar

Pakistan

*Corresponding author; email: weedscientist@aup.edu.pk

Received: 29 October 2013

Accepted: 12 June 2014 